\title{
RESPONSES OF SMALL MAMMAL COMMUNITIES TO PINYON-JUNIPER HABITAT TREATMENTS
}

\author{
Mark E. Peterson ${ }^{1,4}$, Cynthia E. Rebar ${ }^{1}$, Karen S. Eisenhart ${ }^{2}$, and Denise I. Stetson ${ }^{1,3}$
}

\begin{abstract}
AвSTRACT.-Small mammals should be considered in wildlife management decisions because they are an important component of ecosystems. We examined small mammal population abundances $(N)$ on 4 habitat treatment types in Colorado pinyon pine (Pinus edulis)-Utah juniper (Juniperus osteosperma) woodlands on the Uncompahgre Plateau, Montrose, Colorado. We trapped small mammals in Sherman live traps on 4 habitat treatment types-including 2 types of management treatments (chaining, roller chop), sites with high drought-related mortality of pinyon pine, and sites of mature pinyon-juniper (PJ) woodland—on 3 mesas. We modeled detection probability of deer mice (Peromyscus maniculatus) and least chipmunks (Tamias minimus) as a function of 4 treatment types on 3 mesas during 2 trapping periods by using Huggins closed mark-recapture models. A variance components analysis was conducted to obtain abundance shrinkage estimates and to separate spatial process variance from the sampling variance to calculate the percent of variation in abundance estimates explained by treatment type, mesa, and trapping period. Abundance estimates were higher for deer mice and least chipmunks on chaining and roller chop treatment sites than on mature PJ woodland and pinyon pine natural mortality sites. The highest percent of variation in abundance estimates was explained by treatment type for deer mice (33.67\%) and least chipmunks $(61.45 \%)$ and secondarily by mesa for deer mice $(21.64 \%)$. We calculated species diversity using Shannon's, Simpson's, Pielou's evenness, and species richness indices, and we used analysis of variance to test for significant differences $(P<0.05)$ in species composition. Species diversity and richness were higher on natural mortality sites than on chaining, roller chop, and mature woodland sites. Our results indicate that chaining and roller chop habitat treatments within PJ woodlands have a positive impact on deer mouse and least chipmunk abundances, whereas natural mortality and chaining treatments have a positive impact on small mammal composition.
\end{abstract}

Resumen.-Los mamíferos pequeños deben ser considerados en las decisiones del manejo de la fauna y flora silvestres porque son un componente importante en los ecosistemas. Nosotros hemos examinado las abundancias de la población de mamíferos pequeños $(N)$ en cuatro tipos de tratamiento hábitats de bosques de piñón de Colorado (Pinus edulis), enebro de Utah (Juniperus osteosperma, PJ) en bosques en Uncompahgre Plateau, Montrose, Colorado. Atrapamos pequeños mamíferos vivos en las trampas Sherman no letales en cuatro tipos de tratamientos de habitat, incluyendo dos tipos de tratamiento de manejo (en áreas cortadas con sierra y picadas con rodillo picado), sitios con alta mortalidad relacionada con la sequía de los árboles de piñon y sitios de piñon-enebro (PJ) de bosques maduros en tres mesas. Modelamos la probabilidad de detección de ratones ciervos (Peromyscus maniculatus) y ardillas listadas (Tamias minimus) como una función de cuatro tipos de tratamiento en tres meses y durante dos períodos de captura usando modelos cerrados de marca-recaptura de Huggins. Un análisis de la varianza de los componentes fue realizado para calcular la disminución de la abundancia y separar el proceso de varianza espacial de la varianza de la muestra y así calcular el porcentaje de variación en estimaciones de abundancia explicadas por el tipo de tratamiento, mesa, y periodo de captura. Las estimaciones de abundancia eran más altas para ratones ciervos y para ardillas listadas en áreas cortadas con sierra y picadas con rodillo picador que en bosques maduros PJ y en áreas de mortalidad natural de piñón enebro. El porcentaje más alto de variación en estimaciones de abundancia fue explicado por el tipo de tratamiento para ratones ciervos (33.67\%) y ardillas listadas $(61.45 \%)$ y secundariamente por mesa para ratones ciervos $(21.64 \%)$. Se calculó la diversidad de especies usando los índices de Shannon, Simpson, Evenness y riqueza de especies y se utilizó el análisis de varianza para probar diferencias significativas $(P<0.05)$ en la composición de especies. La diversidad y riqueza de especies fueron mayores en áreas de mortalidad natural que en áreas cortadas con sierra, picadas con rodillo picador, y sitios de bosques maduros. Nuestros resultados indican que los tratamientos de hábitats cortados con sierra y picados con rodillo dentro de los bosques PJ tienen un impacto positivo sobre las abundancias de ratones ciervos y ardillas listadas, mientras que los sitios de mortalidad natural tienen un impacto positivo sobre la composición de pequeños mamíferos.

Pinyon-juniper (PJ) woodlands composed predominately of Pinus spp. and Juniperus spp. occupy approximately 40 million hectares throughout Arizona, Colorado, Nevada, New
Mexico, and Utah, representing one of the largest discontinuous woodlands in the southwestern United States (West 1999, Romme et al. 2009). Pinyon-juniper communities have

${ }^{1}$ Department of Biology, Edinboro University, 230 Scotland Drive, Edinboro, PA.

${ }^{2}$ Department of Geosciences, Edinboro University, 230 Scotland Drive, Edinboro, PA

${ }^{3}$ Present address: National Ecological Observatory Network, Pacific Northwest Region, 1211 Cardinal Court Suite 120, Vancouver, WA.

4Present address: South Dakota Department of Game, Fish and Parks, 4130 Adventure Trail, Rapid City, SD. E-mail: mark.peterson313@gmail.com 
significant recreational values for humans and provide vital habitat for many wildlife species, particularly elk, mule deer, birds, and a variety of small mammals. Land managers believe that forested landscapes and woodlands throughout the western United States are under considerable stress, partially due to harmful human recreational use and past management practices. Past management practices, such as fire suppression and extensive livestock grazing, may be causing some PJ woodlands to encroach into shrublands and grasslands (Blackburn and Tueller 1970, Burkhardt and Tisdale 1976, Albert et al. 2004), though this might not be the case for all PJ woodlands (Romme et al. 2009). Nonetheless, concern about PJ encroachment has led land managers to implement habitat treatments that reduce the woodland overstory in order to reinvigorate the shrub and ground layers. More recently, since 2002, some landscapes where pinyon pine appeared to have encroached into shrublands have subsequently experienced a major die-off of pinyon pine in response to persistent drought (Breshears et al. 2005, Floyd et al. 2009, Romme et al. 2009). Die-off of a dominant tree species might be expected to reinvigorate the understory. However, in some areas where extensive pinyon pine mortality occurred, patches of bare soil may persist. Thus, land managers continue to apply habitat treatments to current and former PJ woodlands with the goal of increasing the woodlands' ability to continually provide food, water, and shelter for wildlife (Lewis et al. 2003).

Until recently, a major objective of conversion from mature PJ woodlands to grasslands was to improve cattle grazing areas (Redmond et al. 2013, Gallo et al. 2016). More recently, PJ removal has been conducted to enhance understory vegetation and habitat for big game species (O'Meara et al. 1981, Skousen et al. 1989, Bergman et al. 2014), commonly via chaining (Redmond et al. 2014), but historically chained areas can negatively impact mammal and bird communities (Gallo et al. 2016, Gallo and Pejchar 2017) and vegetation structure (Redmond et al. 2013). Chaining occurs when medium and large trees are uprooted in both directions by a boat anchor chain attached to the back of 2 bulldozers, with vegetation slash left behind on the landscape (Short and McCulloch 1977, Bureau of Land Management 2008). However, chaining is not very effective at killing smaller trees (Aro 1971). Thus, a new method, roller chopping, was developed. Roller chopping is implemented by pulling a large steel cylindrical drum equipped with several blades behind a bulldozer (BLM 2008). Roller chopping causes a nearly $100 \%$ reduction in tree canopy by uprooting all vegetation with the bulldozer blade and mechanically masticating newly downed vegetation with the drum, leaving coarse woody debris and no slash. This method encourages establishment of grasses, shrubs, and forbs that are reseeded into the site. To the extent that the woodland conversion is successful, it should benefit a number of wildlife types in addition to big game, such as birds and small mammals (Gallo and Pejchar 2016).

Small mammals are an important component of PJ ecosystems, as they are important seed predators and dispersers (Vander Wall and Balda 1981, Hollander and Vander Wall 2004, Vander Wall 2008) and thus have a large impact on the development of vegetative communities (Vander Wall 1990, Somers et. al. 2003, Muñoz and Bonal 2011). As granivores, rodents have the capacity to remove seeds through seed predation or to disperse seeds through seed larders or scatterhoarding (Vander Wall 1990, 1997). However, not all seeds that are cached are recovered and eaten, thus some seeds may germinate in the spring or summer and establish seedlings in suitable microsites (Chambers et al. 1999, Vander Wall 2002, 2008). In addition to caching, rodents may pilfer and recache seeds, possibly to suitable microsites (Vander Wall 2002, Muñoz and Bonal 2011). Through seed predation and seed dispersal, then, small mammal populations have the potential to strongly impact the future distribution and structure of trees, shrubs, forbs, and grasses. Small mammal diversity and abundance, therefore, is likely to impact the successional trajectory of treated areas.

Previous studies have focused on the effect of habitat treatments on small mammal communities because of the biological importance of small mammals as granivores (Turkowski and Reynolds 1970, Baker and Frischknecht 1973, O’Meara et al. 1981, Sedgwick and Ryder 1987). Small mammals are also an important food source for a number of other wildlife (Holechek 1981). Because small mammals are important components of PJ ecosystems, they should be considered in wildlife 
management decisions. However, few studies have examined the long-term effects of habitat treatments on small mammal abundance and diversity (Bombaci and Pejchar 2016) specifically on chaining and roller chop sites, and no studies of this kind have been conducted on the Uncompahgre Plateau.

Our study analyzed the effects of Colorado pinyon pine (Pinus edulis) and Utah juniper (Juniperus osteosperma) habitat treatments on small mammal populations on the Uncompahgre Plateau in southwestern Colorado. Populations were sampled in 4 different treatment types across 3 different mesas during 2 trapping periods. Treatment types included 2 types of management treatments (chaining [about 40-50 years posttreatment], and roller chop [about 1-4 years posttreatment]), sites with presumably high drought-related mortality of pinyon pine, and mature PJ woodland sites. A priori, we hypothesized that small mammal abundance would be higher on chaining and roller chop treatment sites than on pinyon pine natural mortality and mature PJ woodland sites. Higher abundance was expected on management treatment sites because of enhanced ground-level vegetation growth and production of coarse woody debris and slash, which are favored by small mammals for food and shelter. We also hypothesized that abundance would vary by mesa because treatments were conducted in different years depending on mesa, plus a main road ran transversely through one mesa. We thought little difference in abundance would occur between the 2 trapping periods because we did not expect differences in small mammal breeding during our study. Consequently, we hypothesized that most of the variation in abundance estimates would be explained by treatment type followed by mesa and minimally by trapping period. Lastly, we hypothesized that species diversity and richness would be higher on natural mortality sites than on management treatment and mature woodland sites. Higher species diversity and richness were expected on the natural mortality sites because more habitat types were present on these sites.

\section{Methods}

\section{Study Area}

The study area was located on the Uncompahgre Plateau, $20 \mathrm{~km}$ southwest of Montrose,
Colorado $\left(30^{\circ} 22^{\prime} \mathrm{N}\right.$ latitude, $108^{\circ} 07^{\prime} \mathrm{W}$ longitude; Fig. 1), and covered $25 \mathrm{~km}^{2}$ with an elevation range of 2070-2370 m. The Uncompahgre Plateau is on the eastern edge of the Colorado Plateau, and 4 main drainages of the Colorado River encompass the plateau, with the Gunnison and Uncompahgre rivers to the east and north and the San Miguel and Dolores rivers to the west and south. The northeast-facing flank of the Uncompahgre Plateau gradually rises to a long ridgeline and is divided by many deep canyons that run perpendicular to the summit ridge. The deep canyons effectively divide the east side of the Uncompahgre Plateau into several long, parallel mesa tops that may limit small mammal dispersal from one mesa to the next. Pinyonjuniper woodland climate is characterized by cool, wet winters and hot, dry early summers, with a wet late-summer monsoon (Hassler 2006). During our study, precipitation averaged $0.79 \mathrm{~cm}$, minimum temperature averaged $11.7^{\circ} \mathrm{C}$, and maximum temperature averaged $31.5^{\circ} \mathrm{C}$ in Montrose, Colorado (National Climatic Data Center 2013).

\section{Habitat Treatment Types}

We identified 4 treatment types along a PJ woodland-shrubland gradient on our study area, namely roller chop, chaining, pinyon pine natural mortality, and mature PJ woodland treatment sites (Stetson 2007, Peterson 2009). We did not sample vegetation, but characterized sites based on vegetation structure and density of the understory. Roller chop treatment sites were classified as areas where roller chopping was conducted on old chaining sites in 2003, 2004, or 2006 by the Uncompahgre Partnership on U.S. Bureau of Land Management (BLM) land (http://www.western colc.org/partners/\#/uncompahgre-partnership/). Roller chop sites were characterized by no tree canopy cover, moderate shrub/herb cover, moderate amounts of coarse woody debris, and no slash. Chaining treatment sites were classified as areas where chaining was conducted in the 1960s by the BLM, and were characterized by little tree canopy cover, high shrub/herb cover, and slash (i.e., uprooted trees lying on the ground). Pinyon pine natural mortality sites were classified as areas where at least $50 \%$ of pinyon pine trees had died, presumably due to drought conditions while juniper trees were not affected. Natural 


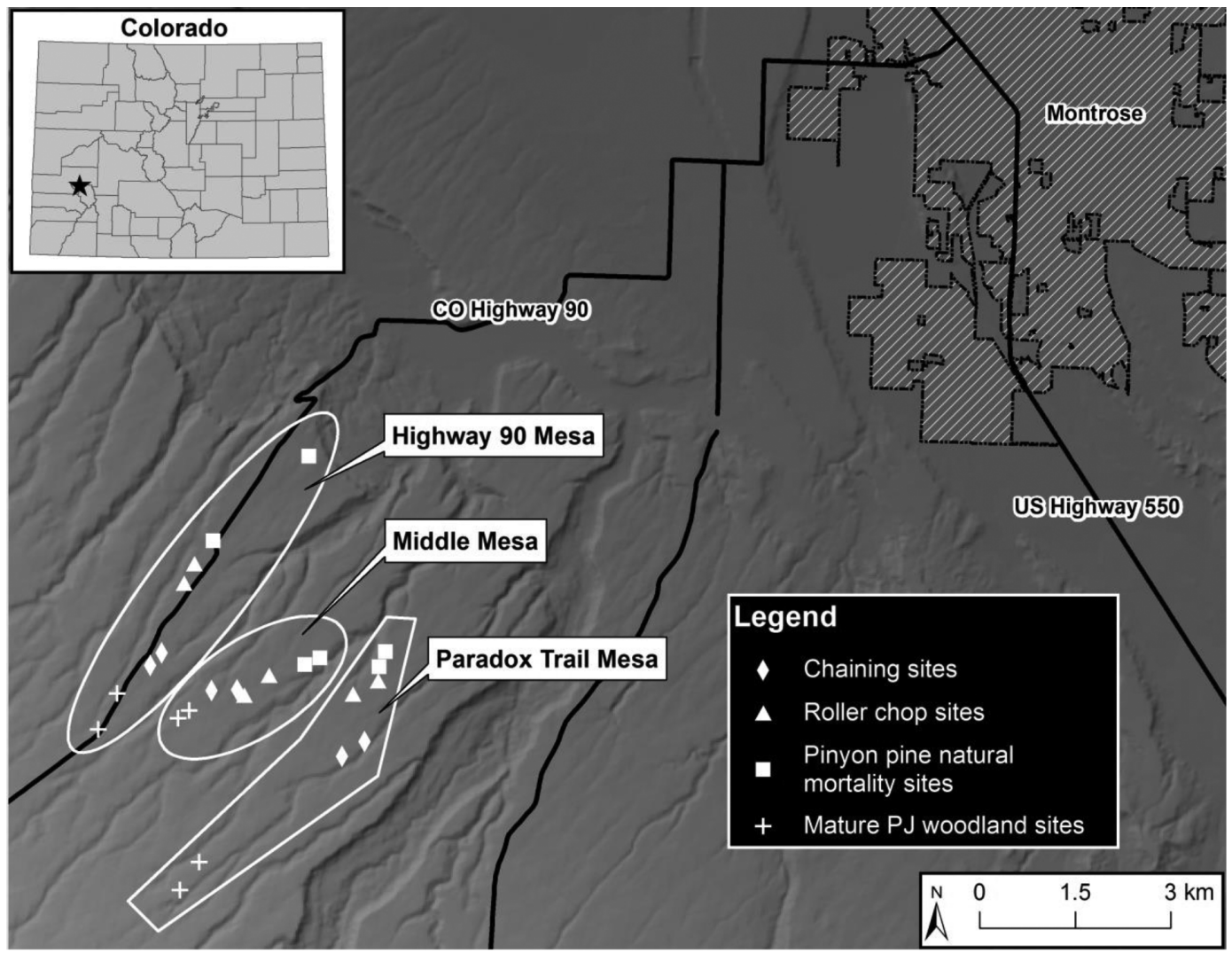

Fig. 1. Locations of small mammal trapping grids of 4 habitat treatment types situated on 3 mesas on the Uncompahgre Plateau, southwestern Colorado, 2007.

mortality sites were characterized by moderate tree canopy cover at this time, moderate shrub/herb cover, and no slash yet, as most pinyon pine trees were still standing and had not fallen over yet. Mature PJ woodland treatment sites were classified as areas where undisturbed, mature stands of trees approximately 200-300 years of age provided high canopy cover with little to no shrub/herb understory and no slash (i.e., control).

Colorado pinyon pine and Utah juniper were the dominant tree types within the study area. Gambel oak (Quercus gambelii), mountain mahogany (Cercocarpus montanus), Utah serviceberry (Amelanchier utahensis), big sagebrush (Artemisia tridentata), and prickly pear cactus (Opuntia spp.) were the dominant species of the mountain shrub community, comprising the understory of the chaining sites, some pinyon pine natural mortality sites, and mature PJ woodland sites. Sagebrush (Artemisia spp.) dominated the understory of low- elevation pinyon pine natural mortality sites. Indian ricegrass (Achnatherum hymenoides), cheatgrass (Bromus tectorum), longflower rabbitbrush (Chrysothamnus depressus), squirreltail (Elymus elymoides), broom snakeweed (Gutierrezia sarothrae), sand dropseed (Sporobolus cryptandrus), muttongrass (Poa fendleriana), Sandberg bluegrass (Poa secunda), big sagebrush, black sagebrush (Artemisia nova), and prickly pear cactus were shrubs, halfshrubs, and grasses, both native and nonnative, that were dominant vegetative species on the roller chop treatment sites.

\section{Small Mammal Trapping Protocol}

We trapped small mammals on roller chop, chaining, pinyon pine natural mortality, and mature PJ woodland treatment sites on 3 mesas (Stetson 2007, Peterson 2009). The mesas were named Highway 90 mesa, Middle mesa, and Paradox Trail mesa and were separated by deep canyons, with the closest trapping grids 
from adjacent mesas separated by a minimum of $1 \mathrm{~km}$. We established 2 trapping grids of each treatment type on the 3 mesas for a total of 24 trapping grids. Each grid was $60 \times 60 \mathrm{~m}$ with $10 \mathrm{~m}$ between trap stations for a total of 49 traps per grid. We placed a single Sherman folding live trap $(7.6 \times 8.9 \times 22.9 \mathrm{~cm}$; H.B. Sherman Traps, Inc., Tallahassee, FL) at each trap station with no regard to the direction of the trap opening. To minimize heat stress on trapped small mammals, we placed shade covers (i.e., bisected 25.4-cm-diameter PVC pipe cut to a length of $26.7 \mathrm{~cm}$ ) over the traps to prevent direct sunlight exposure.

We trapped during an early trapping period from 27 May 2007 to 26 June 2007 and a late trapping period from 6 July 2007 to 4 August 2007. During each trapping period, we conducted mark-recapture trapping for 3 consecutive nights on a trapping grid for each of the 4 treatment types on one mesa simultaneously, and then trapped on a different mesa (i.e., groups of 4 grids trapped on each of the 3 mesas during twelve 3-day sampling occasions). We alternated trapping such that time effects were balanced across treatment types and mesa with a minimum of 18 days between trapping on each group of 4 grids. No trapping took place from the day before until the day after a full moon because of decreased rodent activity (Kaufman and Kaufman 1982). We set traps at 16:00, baited them with unhusked sunflower seeds, placed a wad of cotton batting at the back of each trap for insulation, then checked traps at 06:00 and closed them until the evening. We identified, sexed, and weighed captured individuals and attached a Monel small mammal \#1 eartag (National Band and Tag Company, Newport, KY) to one ear for future identification. Capture and handling procedures followed guidelines of the American Society of Mammalogists (Sikes et al. 2016).

\section{Statistical Analyses}

We utilized Program MARK (White and Burnham 1999) and Huggins closed-capture models (Huggins 1989, 1991) to estimate detection probability $(p)$, estimate recapture probability $(c)$, and obtain a derived abundance estimate $(N)$ of deer mice (Peromyscus maniculatus) and least chipmunks (Tamias minimus), the 2 most commonly captured species, for each trapping grid. Huggins models are robust to low sample sizes, as with our sparse data.
We wanted the most general model for describing the detection process from which to derive abundance estimates for further analysis. A priori, we hypothesized that detection probability could be a function of time (i.e., Julian day), trapping grid, treatment type, mesa, and/or trapping period. We also thought that recapture probability could include a behavioral response in which small mammals can become more or less difficult to recapture (i.e., different detection and recapture probabilities). We determined the most general model structure for detection probability. Only results from models that converged were included.

After we determined the most general model for detection, we analyzed the variability in the derived deer mouse and least chipmunk abundance estimates for each trapping grid by treatment type, mesa, and trapping period using a variance components analysis in program MARK (White et al. 2001). A variance components analysis allowed us to focus on the biological process variance of treatment type, mesa, and trapping period effects by separating out the sampling variance for each effect (White 2000, Burnham and White 2002). We calculated the percent of process variation in abundance estimates explained by treatment type, mesa, and trapping period as well as shrinkage abundance estimates (Burnham and White 2002) for each treatment type and used these estimates when presenting abundance estimates.

We estimated species diversity using Shannon's, Simpson's, Pielou's evenness, and species richness (i.e., total number of distinct species captured) indices (Smith and Smith 2001). We fit analysis of variance (Zar 2009) models and used Tukey's post hoc comparisons to evaluate differences in species composition among mesas and treatment sites and between trapping periods in the $\mathrm{R}$ statistical software (R Core Team 2015).

\section{Results}

We captured and marked 6 species of small mammals (Appendix 1), including deer mice ( $n=340 ; 653$ captures), least chipmunks $(n=$ 202; 338 captures), pinyon mice (Peromyscus truei; $n=41 ; 83$ captures), long-tailed voles (Microtus longicaudus; $n=2 ; 2$ captures, caught on roller chop sites), a Mexican 


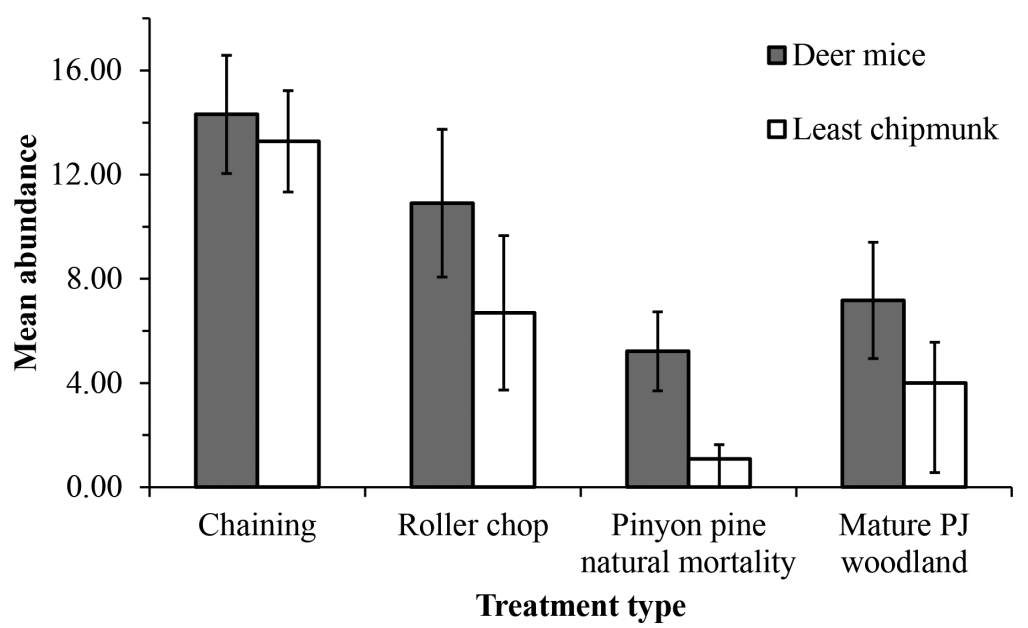

Fig. 2. Deer mouse and least chipmunk abundance estimates by treatment type averaged across mesas and trapping periods on the Uncompahgre Plateau, southwestern Colorado, 2007. Error bars represent 95\% confidence intervals around the mean.

TABLE 1. Variance components analysis results for percent of process variation in deer mouse and least chipmunk abundance estimates explained by treatment type, mesa, and trapping period on the Uncompahgre Plateau, southwestern Colorado, 2007. The mean model estimated a process variance of 24.23 (95\% CI 15.21-42.43) for deer mice and 31.63 (95\% CI 19.16-55.13) for least chipmunks.

\begin{tabular}{llcrrr}
\hline Species & Effect & Process variance & 95\% LCL & 95\% UCL & $\begin{array}{c}\text { Percent of } \\
\text { variation explained }\end{array}$ \\
\hline Deer mouse & Treatment type & 16.07 & 9.71 & 29.32 & 33.67 \\
& Mesa & 18.99 & 11.46 & 34.73 & 21.64 \\
\multirow{2}{*}{ Least chipmunk } & Trapping period & 22.70 & 14.28 & 39.75 & 6.33 \\
& Treatment type & 12.19 & 6.73 & 23.15 & 61.45 \\
& Mesa & 32.47 & 19.60 & 56.99 & 2.56 \\
& Trapping period & 29.46 & 17.76 & 51.64 & 6.86 \\
\hline
\end{tabular}

woodrat (Neotoma mexicana; $n=1 ; 1$ capture, caught on chaining site), and a Perognathus sp. ( $n=1 ; 1$ capture, caught on a roller chop site). We captured 28, 12, 1 , and 0 unique pinyon mice on natural mortality, chaining, roller chop, and mature woodland sites, respectively.

\section{Abundance}

The most general model for deer mouse detection probability that our data could support modeled detection as a function of trapping grid and behavioral response. Deer mouse abundances were higher on chaining and roller chop treatment sites than on pinyon pine natural mortality and mature PJ woodland sites (Fig. 2), and treatment type explained the most variance in deer mouse abundance estimates (33.67\%; Table 1), supporting our hypothesis. Deer mouse abundance averaged across treatment types and trapping periods was 11.88 (SE 5.79) on Highway 90 mesa, 9.24 (SE 5.07) on Middle mesa, and 6.69 (SE 3.21) on Paradox Trail mesa. Mesa also explained some of the process variance in deer mouse abundance estimates (21.64\%; Table 1), which also supported our hypothesis. Lastly, deer mouse abundance averaged across treatment type and mesa was lower during the early trapping period $(N=$ 7.27, SE 4.83) than the late trapping period $(N$ $=11.53$, SE 5.01). Trapping period explained the least process variance in deer mouse abundance estimates (6.33\%; Table 1), suggesting it had little effect on abundance estimates.

The most general model for least chipmunk detection probability that our data could support modeled detection as a function of time, treatment type, mesa, and trapping period. Least chipmunk abundances were higher on chaining and roller chop treatment 
TABLE 2. Analysis of variance results for species diversity and richness indices of small mammals on 4 habitat treatment types, on 3 mesas, and during 2 trapping periods on the Uncompahgre Plateau, southwestern Colorado, 2007. Means are given with standard errors in parentheses. Different letters indicate significant differences $(P<0.05)$ within columns for mesa, treatment type, or trapping period.

\begin{tabular}{|c|c|c|c|c|}
\hline & \multicolumn{4}{|c|}{ Index } \\
\hline & Shannon's & Simpson's & Pielou's evenness & Species richness \\
\hline \multicolumn{5}{|l|}{ Treatment type } \\
\hline Roller chop & $0.69(0.04) \mathrm{a}$ & $0.45(0.03) \mathrm{a}$ & $0.84(0.09) \mathrm{a}$ & $2.50(0.34) \mathrm{a}, \mathrm{b}$ \\
\hline Chaining & $0.83(0.06)$ a,c & $0.53(0.02)$ a,c & $0.85(0.06) \mathrm{a}$ & $2.83(0.31) \mathrm{b}$ \\
\hline Natural mortality & $0.97(0.04) \mathrm{c}$ & $0.59(0.03) \mathrm{c}$ & $0.88(0.04) \mathrm{a}$ & $3.00(0.00) \mathrm{b}$ \\
\hline Mature woodland & $0.34(0.07) \mathrm{b}$ & $0.19(0.01) b$ & $0.49(0.11) b$ & $1.83(0.17) \mathrm{a}$ \\
\hline \multicolumn{5}{|l|}{ Mesa } \\
\hline Highway 90 & $0.66(0.09) \mathrm{a}$ & $0.41(0.02) \mathrm{a}$ & $0.74(0.08) \mathrm{a}$ & $2.50(0.19) \mathrm{a}$ \\
\hline Middle & $0.66(0.11) \mathrm{a}$ & $0.44(0.07) \mathrm{a}$ & $0.76(0.12) \mathrm{a}$ & $2.38(0.32) \mathrm{a}$ \\
\hline Paradox Trail & $0.80(0.09) \mathrm{a}$ & $0.48(0.05) \mathrm{a}$ & $0.81(0.05) \mathrm{a}$ & $2.75(0.34) \mathrm{a}$ \\
\hline \multicolumn{5}{|l|}{ Trapping period } \\
\hline Early & $0.71(0.10) \mathrm{a}$ & $0.43(0.05) \mathrm{a}$ & $0.68(0.08) \mathrm{a}$ & $2.42(0.16) \mathrm{a}$ \\
\hline Late & $0.70(0.06) \mathrm{a}$ & $0.44(0.04) \mathrm{a}$ & $0.85(0.05) \mathrm{a}$ & $2.33(0.12) \mathrm{a}$ \\
\hline
\end{tabular}

sites than on pinyon pine natural mortality and mature PJ woodland sites (Fig. 2), and treatment type explained the most variance in least chipmunk abundance estimates $(61.45 \%$; Table 1), supporting our hypothesis. Least chipmunk abundance averaged across treatment types and trapping periods was 7.30 (SE 6.38) on Highway 90 mesa, 6.57 (SE 5.79) on Middle mesa, and 4.87 (SE 4.73) on Paradox Trail mesa. Mesa explained little process variance in least chipmunk abundance estimates (2.56\%; Table 1), suggesting it had little effect on abundance estimates, which went against our hypothesis. Least chipmunk abundance averaged across treatment types and mesas was lower during the early trapping period $(N=$ 4.47, SE 4.68) than the late trapping period $(N$ $=7.99, \mathrm{SE}$ 6.04). Trapping period explained little process variance in least chipmunk abundance estimates $(6.86 \%$; Table 1$)$, suggesting it had little effect on abundance estimates.

\section{Species Diversity}

Shannon's, Simpson's, Pielou's evenness, and species richness indices showed significant differences among treatment types $(P \leq$ 0.01; Table 2). Tukey's post hoc testing indicated significant differences $(P<0.05)$ between chaining and mature woodland sites and between natural mortality and mature woodland sites for all 4 indices (Table 2). Tukey's testing also indicated significant differences $(P<0.05)$ between roller chop and mature woodland sites for Shannon's, Simpson's, and Pielou's evenness indices (Table 2). Additionally, Tukey's testing indicated signifi- cant differences $(P<0.05)$ between natural mortality and roller chop sites for Shannon's and Simpson's indices (Table 2). Mean species diversity was higher on natural mortality sites than on chaining sites, which had a higher mean species diversity than roller chop and mature woodland sites for Shannon's and Simpson's indices (Table 2), supporting our hypothesis. Species richness was higher on natural mortality sites than on chaining and roller chop sites; lowest richness was found on mature woodland sites (Table 2), supporting our hypothesis. We found no significant differences $(P>0.05)$ among mesas or between trapping periods for all 4 indices.

\section{Discussion}

Several habitat differences (e.g., canopy cover, shrub and herb cover, coarse woody debris, slash, and bare soil) between treatment types could influence small mammal populations on the Uncompahgre Plateau. Similar to other studies, we found higher small mammal abundance on chaining treatment sites where the overstory of mature trees had been uprooted (Turkowski and Reynolds 1970, Baker and Frischknecht 1973, O'Meara et al. 1981, Sedgwick and Ryder 1987). Chaining treatment sites typically develop a greater variety and abundance of herbaceous and shrubby vegetation than mature woodland sites (O'Meara et al. 1981, Redmond et al. 2013). Chaining sites in our study area have been recovering since the 1960s and thus also included several pinyon pine and juniper trees 
of various sizes that occurred both sparsely and clumped together. Additionally, slash on chaining treatment sites provides a number of microhabitats and food sources that could be used by small mammals (Turkowski and Reynolds 1970, Baker and Frischknecht 1973, Severson 1986).

We also found high abundances of deer mice and least chipmunks on roller chop treatment sites, and ours is the first published record of small mammal abundances in this type of habitat treatment. Just as for chaining treatment sites, we noted a greater variety and abundance of herbaceous and shrubby vegetation on roller chop sites than on mature woodland sites. Likewise, coarse woody debris on roller chop treatment sites provides small mammals with building material for shelter and nest construction (Albert et al. 2004).

In contrast, mature PJ woodland sites had a much more open understory, with sparse shrubs, forbs, grasses, and woody debris under a fairly continuous tree canopy, which limited sunlight penetration to the ground, possibly contributing to fewer microhabitats and food resources. Deer mice are opportunistic in food habits (Johnson 1961) and almost exclusively use ground-level resources (Holbrook 1978), so the lack of ground-level resources at mature PJ woodland sites possibly contributed to lower abundances of deer mice compared to chaining or roller chop treatment sites.

The understory of natural morality sites, on the other hand, was dominated by greater shrub cover, especially big sagebrush and black sagebrush. In addition, some coarse woody debris from branches of dead trees was on the ground. However, the abundance of deer mice was lowest on the natural mortality sites, possibly because the ground between the shrubs was relatively bare and open. Most of the dead trees at the natural mortality sites had died recently and had not yet fallen, so it is possible that over time these sites will become more suitable habitat for deer mice as the dead trees fall and tree canopy becomes increasingly sparse. Thus, it appears that the varying levels of grass, forb, shrub, slash, and tree cover likely contributed to treatment type being the effect in this study that most strongly explained variation in deer mouse abundances.

Least chipmunks prefer to live among shrubs, especially sagebrush, even where trees are available (Linsdale 1938, Feldhamer 1979). Thus, increased shrub cover on chaining and roller chop treatment sites likely favored these species (O'Meara et al. 1981). Though least chipmunk abundance on natural mortality sites was lower than on chaining or roller chop treatment sites, it was greater than abundance on mature PJ woodland sites. Open canopies on chaining and roller chop treatment sites may allow least chipmunks to detect aerial predators and quickly escape to their burrows (Feldhamer 1979). Least chipmunks frequent their burrows during hot temperatures to reduce body heat (Heller and Poulson 1972), which is likely necessary to inhabit chaining and roller chop treatment sites with fairly open canopies. Thermoregulatory strategies for coping with inhabiting habitat treatment sites likely contributed further to treatment type being the effect that most strongly explained variation in least chipmunk abundances.

Deer mice are highly adaptable and recolonize newly cleared areas (Gashwiler 1959, Albert et al. 2004, Converse et al. 2006a, 2006b), and least chipmunks prefer to live among shrubs (Feldhamer 1979). Differing deer mouse and least chipmunk abundances on mesas suggest that spatial and temporal differences existed over the study area. Roller chop treatment sites were treated in 2006 on Paradox Trail mesa, which limited the amount of aboveground biomass accumulation, whereas roller chop treatment sites were treated in 2004 on Highway 90 mesa and in 2003 on Middle mesa, allowing a longer time for regrowth. Consequently, greater aboveground biomass accumulation may have been present to provide small mammals with preferable habitat conditions, such as shrub structure and composition (O’Meara et al. 1981), or it may be that heterogeneous habitat surrounding roller chop sites provided source populations. Thus, temporal differences of treatment types on each mesa may have contributed to some of the variation in deer mouse abundances because of differing aboveground biomass accumulation or colonization of sites from source populations. Further, a main road runs through Highway 90 mesa, possibly contributing to disturbed habitat that generalist deer mice found more suitable, which likely impacted rodent predators. Thus, spatial differences of mesas could have contributed to some of the variation in deer mouse abundances. However, 
mesa did not explain variation in least chipmunk abundances, possibly because animals in recovering treatments emigrated from areas where shrubs had been recently removed (Parmenter and MacMahon 1983). Alternatively, perhaps shrub structure and composition was still fairly homogeneous across mesas and therefore did not contribute to variation in abundances.

Total captures for pinyon mice were not statistically analyzed due to the low number of captures, but patterns were present. We captured pinyon mice on all 6 natural mortality sites, 5 chaining sites, 1 roller chop site, and 0 mature woodland sites. Turkowski and Watkins (1976) found that pinyon mice were caught in greater numbers on unchained sites, supporting our results of more captures on the unchained natural mortality sites. Pinyon mice are most commonly found among junipers (Armstrong et al. 2011), particularly where these trees grow among rocks or on rocky slopes (Rompola and Anderson 2002, Rodhouse et al 2010). In our study area, natural mortality sites were located at lower elevations and had a greater percentage of exposed rocks, juniper trees, and dead pinyon pines. Mortality of so many pinyon pine trees may be shifting natural mortality sites to open shrubland with live juniper trees. Albert et al. (2004) found that small, arboreal mammals, such as pinyon mice, decreased in abundance when pinyon and juniper trees were removed. Similarly, Turkowski and Reynolds (1970) reported that pinyon mouse captures decreased on sites where pinyon and junipers were uprooted. However, natural mortality sites on the Uncompahgre Plateau were experiencing drought-related die-off of only pinyon pine trees without any removal of juniper trees. Furthermore, we observed that the dead pinyon pine trees rot off at their bases and fall over, leaving no root mass above ground. Thus, in the future, pinyon mice may thrive and favor natural mortality sites if the droughttolerant juniper trees that they are associated with persist. In contrast, even though mature woodlands were unchained, we did not capture any pinyon mice at these sites. This may be due to sparse understory and lack of woody debris, since some sites included exposed rocks or were located near mesa edges.

Composition of small mammal communities on each of the 4 treatment sites and mesas showed varying levels of species diversity and richness. O'Meara et al. (1981) found lower species diversity on chaining sites compared to unchained sites, whereas we found higher species diversity on natural mortality sites. Species richness was the highest on natural mortality sites followed by the treated sites and finally mature woodland sites. We expected species diversity and richness to be high on natural mortality and chaining sites because abundant cover possibly provided multiple microhabitats. Sedgwick and Ryder (1987) found higher species richness on chaining sites than on unchained sites, but the comparison was made with pretreatment and control data and did not include natural mortality sites. Species richness was highest in our study on natural mortality sites due to pinyon mice favoring these sites, probably because juniper trees, rocky outcrops, and slopes were present.

Seed dispersal by small mammal populations in conjunction with habitat treatments can potentially influence future vegetation distribution and structure, and therefore should be considered in wildlife management decisions. Past and current habitat treatment strategies have tended to focus primarily on enhancing big game (Skousen et al. 1989, Bergman et al. 2014) and Greater Sage-Grouse (Centrocercus urophasianus; Baruch-Mordo et al. 2013) habitat. Our study demonstrates that chaining and roller chop treatment sites can positively influence deer mouse and least chipmunk abundances in PJ ecosystems, but it is not clear whether this comes at the expense of displacing other more specialist species. For example, pinyon mice were captured in natural mortality sites and chaining sites (which had been recovering since the 1960s), but not in roller chop sites; whereas deer mice were captured in all 4 treatment types, albeit at different abundance levels. The deer mouse is a generalist species that appears to adapt more easily to habitat change, whereas nongeneralist species may be less able to adapt to treatments if they prefer specific habitat, such as standing trees and a diverse understory.

Our results suggest that both deer mice and least chipmunks are abundant on old chaining sites and recent roller chop sites, which suggests that posttreatment community shifts may persist for some time into the future. Thus, land managers may want to 
plan treatments in a way that maintains some habitat for specialist species and effectively improves diversity across the broader landscape. This objective may involve site-specific analyses and monitoring of wildlife communities prior to habitat treatments and periodically during succession following habitat treatments (Block et al. 2001, Gallo et al. 2016) to determine if repeat habitat treatments are necessary to maintain desirable shrubland conditions. Further, land managers should consider the area's vulnerability to drought prior to habitat treatments because natural disturbance might mimic human-driven disturbances by promoting local community diversity. After carefully considering how habitat treatments and drought could affect various taxonomic groups, managers should consider actions to enhance vegetation distribution and structure in a way that best benefits the wildlife community (Bombaci and Pejchar 2016, Gallo and Pejchar 2016, 2017).

\section{ACKNOWLEDGMENTS}

Funding for this research was provided by the Edinboro University of Pennsylvania University Senate Research Grant program, the Pennsylvania State System of Higher Education Faculty Professional Development Councils Annual Grant program, and a Charles Redd Center for Western Studies Summer Grant for Upper Division and Graduate Studies. We thank A. Bell, C. Bell, A. Coates, D. Imbrogno, H. Markel, T. Nardo, R. Salisbury, and E. Williams for field assistance and S. Kirchner for helping with the cutting of trap covers. P.F. Doherty Jr. and G.C. White provided statistical assistance. P.F. Doherty Jr., T. Karels, the Wagar 113 Superpopulation at Colorado State University, and 2 anonymous reviewers provided constructive reviews of the manuscript, and A. Franz-Mamani provided translation of the abstract.

\section{Literature Cited}

Albert, S., N. Luna, R. Jensen, and L. Livingston. 2004. Restoring biodiversity to piñon-juniper woodlands. Ecological Restoration 22:18-23.

Armstrong, D.M., J.P. Fitzgerald, and C.A. Meaney. 2011. Mammals of Colorado. 2nd edition. University Press of Colorado, Boulder, CO.

ARO, R.S. 1971. Evaluation of pinyon-juniper conversion to grassland. Journal of Range Management 24:188-197.

BAKER, M.F., AND N.C. FRISCHKNECHT. 1973. Small mammals increase on recently cleared and seeded juniper rangeland. Journal of Range Management 26:101-103.
Baruch-Mordo, S., J.S. Evans, J.P. Severson, D.E. Naugle, J.D. Maestas, J.M. Kiesecker, M.J. Falkowski, C.A. Hagen, and K.P. Reese. 2013. Saving sagegrouse from the trees: a proactive solution to reducing a key threat to a candidate species. Biological Conservation 167:233-241.

Bergman, E.J., C.J. Bishop, D.J. Freddy, G.C. White, AND P.F. Doherty JR. 2014. Habitat management influences overwinter survival of mule deer fawns in Colorado. Journal of Wildlife Management 78: $448-455$.

Blackburn, W.H., and P.T. Tueller. 1970. Pinyon and juniper invasion in black sagebrush communities in east-central Nevada. Ecology 51:841-848.

Block, W.M., A.B. Franklin, J.P. Ward Jr., J.L. Ganey, AND G.C. White. 2001. Design and implementation of monitoring studies to evaluate the success of ecological restoration on wildlife. Restoration Ecology 9:293-303.

Bombaci, S.P., And L. Pejchar. 2016. Consequences of pinyon and juniper woodland reduction for wildlife in North America. Forest Ecology and Management 365:34-50.

Breshears, D.D., N.S. Cobb, P.M. Rich, K.P. Price, C.D. Allen, R.G. Balice, W.H. Romme, J.H. Kastens, M.L. Floyd, J. Belnap, Et aL. 2005. Regional vegetation die-off in response to global-change-type drought. Proceedings of the National Academy of Sciences 102:15144-15148.

[BLM] Bureau of Land Management. 2008. Integrated vegetation management handbook. U.S. Bureau of Land Management Handbook H-1740-2, Rel. 1-1714.

Burkhardt, J.W., and E.W. Tisdale. 1976. Causes of juniper invasion in southwestern Idaho. Ecology 57:472-484.

Burnham, K.P., AND G.C. White. 2002. Evaluations of some random effects methodology applicable to bird ringing data. Journal of Applied Statistics 29: 245-264.

Chambers, J.C., S.B. Vander Wall, and E.W. Schupp. 1999. Seed and seed ecology of piñon and juniper species in the pygmy woodland of western North America. Botanical Review 65:1-38.

Converse, S.J., W.M. Block, And G.C. White. 2006a. Small mammal population and habitat responses to forest thinning and prescribed fire. Forest Ecology and Management 228:263-273.

Converse, S.J., G.C. White, and W.M. Block. 2006b. Small mammal responses to thinning and wildfire in ponderosa pine-dominated forests of the southwestern United States. Journal of Wildlife Management 70:1711-1722.

Feldhamer, G.A. 1979. Vegetative and edaphic factors affecting abundance and distribution of small mammals in southeast Oregon. Great Basin Naturalist 39:207-218.

Floyd, M.L., M. Clifford, N.S. Cobb, D. Hanna, R. Delph, P. Ford, AND D. Turner. 2009. Relationship of stand characteristics to drought-induced mortality in three Southwestern piñon-juniper woodlands. Ecological Applications 19:1223-1230.

Gallo, T., and L. Pejchar. 2016. Improving habitat for game animals has mixed consequences for biodiversity conservation. Biological Conservation 197:47-52.

Gallo, T., and L. Pejchar. 2017. Woodland reduction and long-term change in breeding bird communities. Journal of Wildlife Management 81:259-268. 
Gallo, T., L.T. Stinson, And L. Pejchar. 2016. Pinyonjuniper removal has long-term effects on mammals. Forest Ecology and Management 377:93-100.

GASHWILER, J.S. 1959. Small mammal study in west-central Oregon. Journal of Mammalogy 40:128-139.

Hassler, F.C., JR. 2006. Dynamics of juniper invaded grasslands and old-growth woodlands at Wupatki National Monument, northern Arizona, USA. Master's thesis, Northern Arizona University, Flagstaff, AZ.

Heller, H.C., AND T.L. Poulson. 1972. Altitudinal zonation of chipmunks (Eutamias): adaptations to aridity and high temperature. American Midland Naturalist 87:296-313.

Holbrook, S.J. 1978. Habitat relationships and coexistence of four sympatric species of Peromyscus in northwestern New Mexico. Journal of Mammalogy $59: 18-26$.

HoLECHEK, J.L. 1981. Brush control impacts on rangeland wildlife. Journal of Soil and Water Conservation 36:265-269.

Hollander, J.L., and S.B. Vander Wall. 2004. Effectiveness of six species of rodents as dispersers of singleleaf pinon pine (Pinus monophylla). Oecologia 138:57-65.

HugGINS, R.M. 1989. On the statistical analysis of capture experiments. Biometrika 76:133-140.

HugGins, R.M. 1991. Some practical aspects of a conditional likelihood approach to capture experiments. Biometrics 47:725-732

Johnson, D.R. 1961. Food habits of rodents on rangelands of southern Idaho. Ecology 42:407-410.

KaUfMan, D.W., and G.A. KaUFMan. 1982. Effect of moonlight on activity of and microhabitat use by Ord's kangaroo rat (Dipodomys ordii). Journal of Mammalogy 63:309-312.

Lewis, P., T. Wardle, D. Leatherman, and J. Duda. 2003. 2002 report on the health of Colorado's forests. Colorado Department of Natural Resources, Division of Forestry, Denver, CO.

LiNSDALE, J.M. 1938. Environmental responses of vertebrates in the Great Basin. American Midland Naturalist 19:1-206.

MuÑoZ, A., AND R. BONAL. 2011. Linking seed dispersal to cache protection strategies. Journal of Ecology 99:1016-1025.

[NCDC] National Climatic Data Center. 2013. NCDC homepage. [Accessed 18 April 2014.] http://www.ncdc .noaa.gov

O’Meara, T.E., J.B. Haufler, L.H. Stelter, and J.G. NAGY. 1981. Nongame wildlife responses to chaining of pinyon-juniper woodlands. Journal of Wildlife Management 45:381-389.

Parmenter, R.R., and J.A. MacMahon. 1983. Factors determining the abundance and distribution of rodents in a shrub-steppe ecosystem: the role of shrubs. Oecologia 59:145-156.

Peterson, M.E. 2009. Responses of small mammal communities to pinyon-juniper reduction on the Uncompahgre Plateau in southwest Colorado. Master's thesis, Edinboro University of Pennsylvania, Edinboro, PA.

R Core Team. 2015. R: a language and environment for statistical computing. R Foundation for Statistical Computing, Vienna, Austria.

Redmond, M.D., N.S. CobB, M.E. Miller, and N.N. BARGER. 2013. Long-term effects of chaining treatments on vegetation structure in piñon-juniper woodlands of the Colorado Plateau. Forest Ecology and Management 305:120-128.

Redmond, M.D., E.S. Golden, N.S. CobB, and N.N. BARGER. 2014. Vegetation management across Colorado Plateau BLM lands: 1950-2003. Rangeland Ecology and Management 67:636-640.

Rodhouse, T.J., R.P. Hirnyck, and R.G. Wright. 2010. Habitat selection of rodents along a piñon-juniper woodland-savannah gradient. Journal of Mammalogy 91:447-457.

Romme, W.H., C.D. Allen, J.D. Bailey, W.L. BaKer, B.T. Bestelmeyer, P.M. Brown, K.S. Eisenhart, M.L. Floyd, D.W. Huffman, B.F. Jacobs, et al. 2009. Historical and modern disturbance regimes, stand structures, and landscape dynamics in piñon-juniper vegetation of the western United States. Rangeland Ecology and Management 62:203-222

Rompola, K.M., and S.H. ANDERSON. 2002. Small mammal community in a juniper-woodland sagebrushgrassland mosaic in southwestern Wyoming. Intermountain Journal of Sciences 8:19-29.

SEDGWICK, J.A., AND R.A. RYDER. 1987. Effects of changing pinyon-juniper on nongame wildlife. Pages 541551 in R.L. Everett, compiler, Proceedings: PinyonJuniper Conference. U.S. Forest Service General Technical Report INT-GTR-215, Reno, NV.

Severson, K.E. 1986. Small mammals in modified pinyon-juniper woodlands, New Mexico. Journal of Range Management 39:31-34.

ShorT, H.L., AND C.Y. McCulloch. 1977. Managing pinyon-juniper ranges for wildlife. General Technical Report RM-47, USDA Forest Service, Fort Collins, CO.

Sikes, R.S., and The Animal Care and Use Committee of the American Society of Mammalogists. 2016. Guidelines of the American Society of Mammalogists for the use of wild mammals in research. Journal of Mammalogy 97:663-688.

Skousen, J.G., J.N. Davis, and J.D. Brotherson. 1989. Pinyon-juniper chaining and seeding for big game in central Utah. Journal of Range Management 42: 98-104.

Smith, R.L., AND T.M. Smith. 2001. Ecology and field biology. 6th edition. Benjamin Cummings, New York.

Somers, P., D.D. Hanna, M. Colyer, and M.L. Floyd. 2003. Mammals of the old-growth piñon-juniper. Pages 111-130 in L.M. Floyd, editor, Ancient piñonjuniper woodlands: a natural history of Mesa Verde country. University Press of Colorado, Boulder, CO.

STETSON, D.I. 2007. Effects of tree removal on small mammal communities on the Uncompahgre Plateau, southwestern Colorado. Doctoral disseratation, Edinboro University of Pennsylvania, Edinboro, PA.

Turkowski, F.J., AND H.G. Reynolds. 1970. Response of some rodent populations to pinyon-juniper reduction on the Kaibab Plateau, Arizona. Southwestern Naturalist 15:23-27.

TurkowsKi, F.J., AND R.K. WatKIns. 1976. White-throated woodrat (Neotoma albigula) habitat relations in modified pinyon-juniper woodlands of southwestern New Mexico. Journal of Mammalogy 57:586-591.

VANDER WaLL, S.B. 1990. Food-hoarding animals as dispersers of plants. University of Chicago Press, Chicago, IL

VANDER WALL, S.B. 1997. Dispersal of singleleaf pinon pine (Pinus monophylla) by seed-caching rodents. Journal of Mammalogy 78:181-191. 
VANDER WALL, S.B. 2002. Masting in animal-dispersed pines facilitates seed dispersal. Ecology 83:3508-3516.

VANDER WaLL, S.B. 2008. On the relative contributions of wind vs. animals to seed dispersal of four Sierra Nevada pines. Ecology 89:1837-1849.

Vander Wall, S.B., and R.P. BaLda. 1981. Ecology and evolution of food-storage behavior in conifer-seed caching corvids. Ethology 56:217-242.

WEST, N.E. 1999. Juniper-piñon savannas and woodlands of western North America. Pages 288-308 in R. Anderson, J. Fralish, and J. Buskin, editors, Savannas, barren, and rock outcrop plant communities of North America. Cambridge University, Cambridge.

White, G.C. 2000. Population viability analysis: data requirements and essential analysis. Pages 288-331 in L. Boitani and T.K. Fuller, editors, Research tech- niques in animal ecology: controversies and consequences. Columbia University Press, New York, NY.

White, G.C., And K.P. BuRnham. 1999. Program MARK: survival estimation from populations of marked animals. Bird Study 46, Supplement:S120-S139.

White, G.C., K.P. Burnham, and D.R. Anderson. 2001. Advanced features of program MARK. Pages 368377 in Proceedings of the Second International Wildlife Management Congress. The Wildlife Society, 28 June-2 July 1999, Gödöllő, Hungary.

ZAR, J.H. 2009. Biostatical analysis. 5th edition. Pearson, Upper Saddle River, NJ.

Received 24 March 2016

Accepted 17 July 2017

Published online 25 September 2017

APPENDIX 1. Number of unique small mammals captured on 4 habitat treatment types and 3 mesas on the Uncompahgre Plateau, southwestern Colorado, 2007.

\begin{tabular}{lcccccc}
\hline & \multicolumn{7}{c}{ Species } \\
\cline { 2 - 7 } & $\begin{array}{c}\text { Deer } \\
\text { mouse }\end{array}$ & $\begin{array}{c}\text { Least } \\
\text { chipmunk }\end{array}$ & $\begin{array}{l}\text { Pinyon } \\
\text { mouse }\end{array}$ & $\begin{array}{c}\text { Long-tailed } \\
\text { vole }\end{array}$ & $\begin{array}{c}\text { Mexican } \\
\text { woodrat }\end{array}$ & $\begin{array}{c}\text { Pocket } \\
\text { mouse }\end{array}$ \\
\hline Treatment type & 104 & 60 & 1 & 2 & 0 & 1 \\
$\quad$ Roller chop & 117 & 102 & 12 & 0 & 0 & 0 \\
Chaining & 51 & 30 & 28 & 0 & 0 & 0 \\
Natural mortality & 68 & 10 & 0 & 0 & 0 & 0 \\
Mature woodland & 152 & 76 & 8 & 2 & 0 & 0 \\
Mesa & 110 & 76 & 10 & 0 & 0 & 1 \\
Highway 90 & 78 & 50 & 23 & 0 & 0 & 1 \\
Middle & & & & & 0 & 0 \\
Paradox Trail & & & & & & 0 \\
\hline
\end{tabular}

